\title{
Figuratively Semantic Analysis of Works of Art
}

\author{
(DValerijs Makarevičs ${ }^{1}$ Dr. psych.; (ODzintra Iliško ${ }^{2}$ Dr. paed. \\ Daugavpils University, Latvia \\ valerijs.makarevics@du.lv¹; dzintra.ilisko@du.lv²
}

\begin{abstract}
Topicality of the study is related to the in-depth study of the art of works of Van Gogh, Velázquez and Repin by relating art to the biography of these authors. The aim of the study is to explore the symbolism and the biography of the painters using the examples of analysis from the works of Van Gogh, Velasquez, and Repin and also to determine the conditions that contribute to the awareness of the process of perception and understanding of paintings. The methodology of this study is figuratively symbolic method used with the purpose to compare the plots of the art and to relate them to the life experience of their creators. Results obtained and the most important conclusions: This is important for the author of a painting to convey his/her thoughts and feelings to the viewer. Still, there remains a problem. The author uses the language of the image and symbol, which the viewer needs to reveal. Psychology of art offers two main options for solving this problem. The essence of the first option which is the ability of the painter to direct the viewer's sight. It is called the Dutch approach. The second approach to the analyses of art is called the Italian approach. In this case this is important to understand the symbolism and knowledge gained historically by relating one's art works to the biography of the painter. The authors of this article focus on the second approach by illustrating it with examples of analysis from the works of Van Gogh, Velázquez, and Repin. The results of this study might be of interest for those who are interested in arts and psychology.
\end{abstract}

Keywords: figuratively symbolic language, painting, creative personality.

\section{Introduction}

Today one needs a society which understands its internal hidden values and is oriented to human. Selfesteem and Self-development during all age stages and in all life spheres (Kalēja-Gasparoviča, 2012). Art has one of the leading roles in this process. Art comprises a spiritual heritage of humanity. Every piece of art has two parts: its creator (the artist, the composer and the producer) and the spectator. Therefore, for the psychology of art the main problems are the study of creative personality and peculiarities of spectators', reader's or listener's perception of art. The psychology of art tries to focus on how the archetypical levels of the human psyche are being revealed in art (Kamali, Javdan, 2012; Vygotsky, 1971).

Creative personality and its peculiarities are the object of the study of social psychology. The peculiarities of a perception of a person - the object of the study of cognitive psychology. Therefore, the current study lies on the border of two psychological disciplines that makes this difficult to find ways of dealing with it. The researchers are looking for the best to find relations between personal peculiarities of the artist, the plot and the peculiarities of art. The study of peculiarities of perception of art has particular topicality (Chauhan, 2015). The main difficulty is that the language of the images used by the artist must be translated into the language of words that help to realize the ideas that the author of the painting and what he or she wanted to convey to the viewer. For this, knowledge of symbolism of the cultural and historical context is needed with which the plot is connected (Makarevičs, 2017). One of the main features of perception is its awareness. Thus, the purpose of our work is to explore the symbolism and the biography of the painters using the examples of analysis from the works of Van Gogh, Velasquez, and Repin and also to determine the conditions that contribute to the awareness of the process of perception and understanding of paintings.

\section{Methodology}

This study applied the method of figurative language for the symbolic analysis of paintings. The spatial, colour, subject symbolism and a symbolism of numbers were analysed for this study.

The analysis of spatial symbolism is based on the symbolism of the cross (Adamcik, 2014). One can illustrate their ideas with the help of a sheet of paper symbolizing a life of a person. In this case, the lower 
left corner will be associated with the beginning of human life, and the upper right - with the completion of the earthly path. Each segment of a paper is associated with primary elements. Lower left segment with water. Upper left segment - with air. Upper right segment - with fire. Human life is determined by the symbolism of water. The goals of life are associated with the symbolism of fire. Hence, the ambiguity lies in the interpretation of these symbols. The symbolism of space is associated with the symbolism of colour. Each of the primary elements has its own colour. The lower left spatial quadrant (water) is coloured blue. Left upper (air) - in yellow. The lower right (ground) - in green. Upper right (fire) - in red. The symbolism of space is also associated with the levels of the psyche. The unconscious symbolizes the lower part of the supposed living space, represented in our example by a sheet of paper. The upper part - the consciousness and the divine component of the essence of a person.

Ideas about the connection between the symbolism of colour and the essential foundations of human life were interpreted by the Swiss scientist, one of the founders of colour psychology, M. Lüscher (Lüscher, 1985), who also proposed his theory of personality typology. It is based on the fact that there are four types of human behaviour. Each of these types of behaviour symbolizes a specific colour. Red is the sexually active type. Yellow - a playful, waiting type that needs support in life. Blue is a calm and rational type. Green - feeling one's vitality, but not inclined to spend it on trifles. This typology, as well as the concept of colour symbolism, which is presented in his work "Four-coloured man" (Lüscher, 2005), the authors use in the analysis of paintings of various historical eras.

For interpretation of subject symbolism, as well as the symbolism of numbers, information was used both in reference books (Hall, 2014), and as a form of specific study of artistic works (Sturgis, Clayson, 2000). The colour symbolism is also studied in connection with the physical characteristics of the colour; it recognizes the existence of a particular language of colour, which is used in different cultures (Gage, 2000).

Among the works devoted to the role of the symbol in the understanding of the idea of a pictorial work, the authors would like to mention as an example the study of M. Battistini. She notes that in previous centuries, symbols were widely used in painting and were understood by the audience. Today, the skill of symbolic reading of the picture is largely lost (Battistini, 2005).

\section{Results and discussion}

\section{The Methods of Analysis of the Characteristics of Understanding of Painting Realistic art}

Various trends in the perception of painting were formulated by the American researcher S. Alpers. She notes that understand European painting this is necessary to know that two traditions were formed in the seventeenth century. One can be conditionally called Italian, the other Danish (Alpers, 1984). According to the author, the Italians read the picture. Thus, they understood its meaning. The Dutch are gazing at the picture. This leads to two trends in the composition of the plots of paintings: the management of perception and the management of meanings. The first trend can be illustrated by Giorgione's Castelfranco Madonna, where the semantic lines display the main character (Giorgione, 1503).

As for the second trend L. Kok offer advice on the perception of artworks and, at the same time, knowledge is ignored, this is the advice of specialists who are latently committed to the Danish tradition of understanding artwork (Kok, 2018). To read the picture requires knowledge. This knowledge, besides knowledge of symbolism, concerns the understanding of the events that formed the basis of the plot, as well as the author's personal life experience (Solso, 2003). To understand the paintings, this is important not only to get acquainted with such art criticism works as a versatile study of historical painting traditions of L. Rideal (Rideal, 2015), or the provision of ready-made recommendations for understanding painting.

First of all, let us explore the works of Van Gogh, R. Huyghe researcher in the field of colour psychology and the creator of the colour psychological history of European painting, notes that knowing that his Ego was coloured yellow helps to understand his work (Huyghe, 1967). This remark by R. Huyghe does not contradict with M. Lüscher's assertion that among the four types of behaviour there is a yellow type. The use of the terminology of colour psychologists, one can note that the conscious and anxious yellow Ego of Vincent Van Gogh was balanced by the desire of the blue unconscious for peace. Therefore, in the most famous paintings of the author uses yellow and blue colours. The tendencies of interaction between yellow and blue behavioural tendencies were caught by the English film director R. Altman. Vincent \& 
Theo is a 1990 biographical drama film about the Dutch painter Vincent van Gogh (1853-1890) and his brother an art dealer Theo (1857-1891). In his film there are several episodes when Van Gogh can be seen standing in front of the easel. And on a piece of paper, it is visible either the contacting blue and yellow colours, or there is a green colour between them (Altman, 1990). The touch of blue and yellow symbolizes the fact that in the soul of Vincent van Gogh there is peace and tranquillity. The invasion of the green indicates that anxiety is settled in his soul (Makarevičs, 2009). From all works of the author the greatest interest for the psychological analysis causes his last picture "Wheatfield and Crows" (Van Gogh, 1890). The picture shows the road going nowhere. It ends in that spatial quadrant, which experts in the field of symbolism of space call a waiting room. Finding the life line in this quadrant (and the road is the actual life line of the author) means the loss of the meaning of his earthly existence. Birds are transcendental symbols. It doesn't matter if they fly away or arrive, which art critics usually pay attention to. They are located on the border of the earthly life of a human being, indicated by the symbolism of space. Here it is a symbol of liberation of the soul from earthly suffering. In the picture, the blue colour touches the yellow field of ripened wheat, the symbol for the realization of the idea of spring. Only the sky is unusually dark blue. The analysis of the elements of the last picture of Van Gogh leads to the idea that here he sums up his creative life and unrealized personal life. In life, he did not receive the main thing - the recognition of his work. This seems that by this picture, he tried to explain his decision to die.

For the figurative and symbolic analysis very interesting is the picture of D. Velázquez: "Christ in the House of Martha and Mary" (Velázquez, 1618). The piece of art represents the relationship of two women, elderly and young, who are located in that part of the house where the food is being cooked. The second is located in the light, unlike the first one who is in the living space of the room. Following the logic of the symbolism of space, one can note that what is happening on the left side of the figure is associated with the present. Second, the right side is associated with the future. In the second part, The Christ speaks with two women - Martha and Maria. At the same time, for the viewer it is not important which of them is Martha, and who is Maria. This is possible that the image of Martha is duplicated in the present and future. The analysis of the spatial and object symbolism of the picture gives us the key to the artist's intention. A woman faces a difficult choice: to follow the traditional requirements for female behaviour. An elderly woman who is in that part of the picture that symbolizes the past, or to choose a spiritual path of development, to become the bearer of spiritual traditions. This will require to complete change of one's usual life, to start it from scratch "ab ovo," as the Latins said.

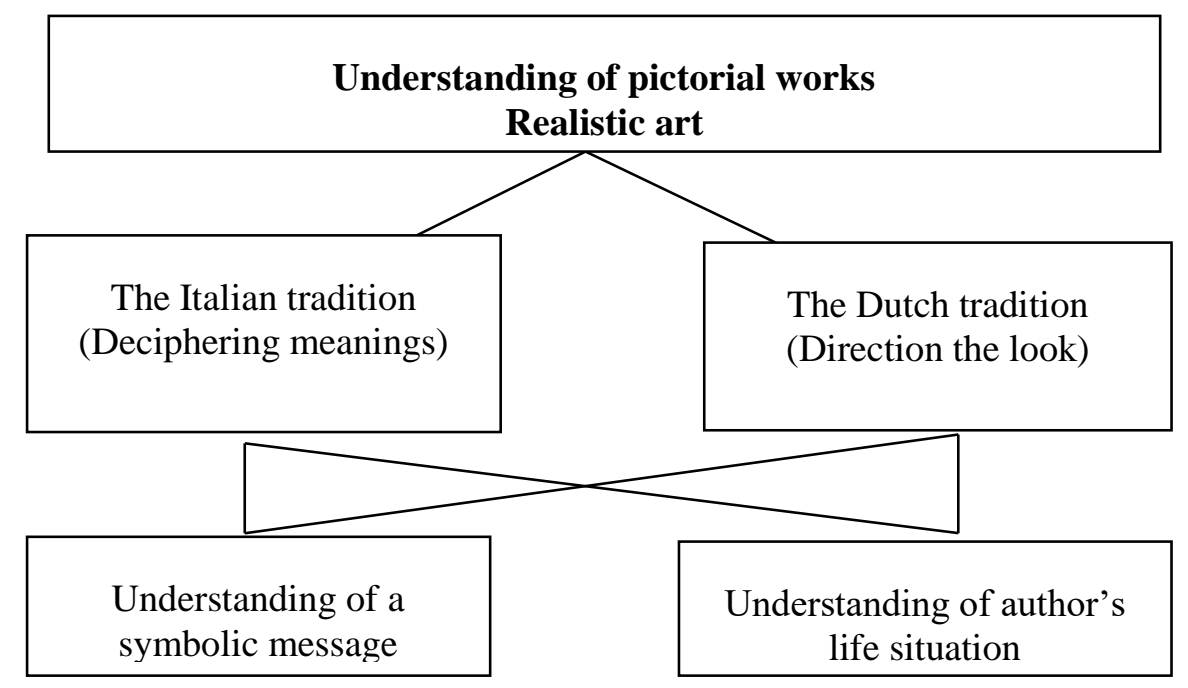

Figure 1. An algorithm for understanding realistic painting.

The image symbolic analysis allows to go for a deeper understanding of the work of the great Russian artist Ilya Repin. Out of all his works, one can single out three works that are associated with his interpretation of the socio-political life of Russia in the second half of the XIX and early XX centuries. These are as following: "Barge haulers on the Volga" (Repin, 1870-1873), "What space!" (Repin, 1903) and "Demonstration on October, 17, 1905" (Repin, 1906). The first picture reflects the technical backwardness of Russia: barge haulers are pulling it into the past. There are no bright colours. However, there are those among the faces of barge haulers that can change the situation. The picture "What space!" 
depicts a turquoise wave and high-school students who rejoice in its appearance. The turquoise wave coming from the future is the expectation of fulfilling hopes for a change in social life. Actors of these changes should be educated young people. But the wave is an element that can not only bring with it the wind of freedom, but also destroy it.

Intuition does not fail the author. The revolution of 1905, which occurred in Russia, did not lead to the desired changes. Referring to the third picture of Repin that depicts jubilant people, in the right outer corner there is a sloppy large red spot. Unlike jubilant people, Repin understands how revolutions end. Figure 1. presents a diagram of the analysis of realistic paintings, which summarizes the information mentioned above.

\section{Abstract painting.}

Now the authors will analyse abstract painting. As an example, consider the work of one of the most famous abstract artists Mark Rothko.

Mark Rothko (Markus Rotkovich) was born in the city of Dvinsk (modern Daugavpils, which is located in the southeast of the Republic of Latvia). At the age of ten, he emigrated with his parents to the United States. There are three periods that can be distinguished in his work: the period of realistic painting, the period of transition from realistic to abstract painting (the surreal stage of creativity) and the period of abstract painting.

In Rothko's homeland, in Daugavpils, in 2013 the Art Center was established as his museum and gallery of modern art. To understand the abstract works of the artist, first of all, this is necessary to consider the first period of his work, or the period of realistic painting. However, in the beginning - a small digression.

In 2003, in Daugavpils the international scientific conference was devoted to Rothko's creativity. It was attended by the children of the artist: daughter Kate and son Christopher. Subsequently, with their permission, computer copies of several abstract works of the painter, as well as the originals of some of his early works, were delivered to the city's museum. Among these early works, one stood out particularly, the plot of which was different from the plots of other paintings. It depicted a deserted city street. This street ran diagonally from the lower left to the upper right and ended with a cliff. Along the street, on both sides, there were high walls. There were no doors in these walls. On the sidewalk, near the wall, on the right side of the street, stood a lonely man. Along the street, towards him, a car with armed people was passing by. This car occupied the entire width of the street.

This picture was soon replaced by others. According to the agreement with the children of Rothko, the exposition is constantly updated. Unfortunately, neither the name nor the year of the picture was recorded. Subsequent searches in catalogues and on the Internet have also failed. The copyright holders did not give it great artistic value. Therefore, they sent it on such a risky journey across the ocean to an unfamiliar country. However, this picture can explain a lot of the work of Mark Rothko.

In the early period of Rothko's work, others paintings differed in plot, but were close in meaning to the picture. Let's consider two of them: "Street scene" painted in 1937 (Rothko, 1937). Actually, the street occupies the fourth part of the picture and is located in its right part. The remaining three quarters depict a type of obstacle. Something remotely resembling ancient Greek buildings. The street in the upper right corner of the picture abruptly goes down and breaks off at an obstacle. There is a small black gap between the street and the obstacle.

The third picture is called "Entrance to the Subway" (Rothko, 1938). It was written in 1938. The painting shows a closed space. Four columns divide the space into four unequal parts. Two columns to the right of the viewer merge with each other. The columns are painted blue and pale yellow. The border between the colours is clear. The picture depicts five characters. All of them are in the central part of the picture, limited by columns to the left and right. Almost all of them (except for one character) are dressed so that the colour of their clothes matches the colour of the interior. Three of these characters stand in a wall opening on a dark brown background (Breslin, 1993).

Two go down the stairs. Moreover, only the beginning of the descent is visible and it is not known what is at its end. One of the characters who descend is dressed in the same pale-yellow robes as those standing 
upstairs in the opening of the wall. The clothes of the second person are painted in a pale red colour. The viewer does not see the faces of the characters. Instead of faces there are yellow spots without any details.

The wall in the background is painted pink. On the left side of the wall, one of its fragments is painted black. Behind the backs of the characters are standing in the opening of the wall, a closed door is visible.

Comparison of the composition of each of these three paintings, allows to conclude that the movement in them occurs along the diagonal going from the upper right corner to the lower left. The direction of movement is shown in Figure 2.

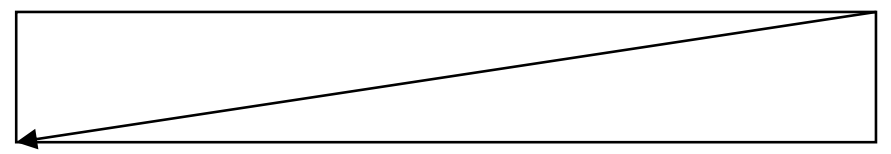

Figure 2. Direction of movement in the Rothko paintings that are selected for analysis.

According to the symbolism of space, the past is located in its left part, the present is in the middle part, and the future is in the right. The line of life goes from the lower left to the upper right. The direction of movement in Rothko's paintings is opposite to the line of life. This can mean either that the characters in the paintings have no future, or that in the future there is something that poses a danger to the present.

The plot of the first picture called "Street Scene" (Rothko, 1937) illustrates the words: The connection of time has been broken. The gap in time here is physically depicted - as a black abyss between the characters of the picture and the stable object located to the left.

The characters of the picture would like to return at a time when the world was stable, reliable and predictable. However, the situation in the world has changed. The destabilization of the situation in the world (time gap) is growing. The careless characters of the picture do not notice this and do not realize it, and, therefore, his compatriots Rothko.

In the work "Entrance to the Subway" (Rothko, 1938), the time boundaries of being are clearly marked. To the left of the column is the past, in the centre is the present, to the right of the column is the future. All characters in the picture are in the present. They face a choice. You can open the door behind. However, what is beyond this door is unknown. One flees from the present to a world connected with the past. This flight and this choice are associated with uncertainty and does not imply the achievement of the expected result (it was seen only the beginning of this path).

Thus, the characters are in a situation of choice without choice. However, they do not realize the danger of a situation in which any choice does not imply their existence in the future (characters have colour spots instead of faces).

The anticipation of a catastrophe is threatening the world, which was manifested in the previous two scenes as a premonition of impending disaster materializes in the third, with a street that is impossible to leave, since there are no exits, and a truck with the military. The prerequisites for war have been created - the truck is moving from the future to the present. And there is no way for an ordinary person to escape from an impending catastrophe.

Rothko's prediction came true. The catastrophe, called World War II (1939-1945) claimed tens of millions of lives, and thousands of prosperous cities and villages were destroyed. The war also affected Rothko a lot. He was shocked by all those events. Why is the person capable of such cruelties?

What is hidden in the deepest parts of his soul? He seeks the answer to this question in the psychoanalytic works of S. Freud (1989) and C.G. Jung (2003). The solutions are found in this way, as well as his own understanding of the essence of the soul of person which he is trying to translate into paintings. Realistic painting is not suitable for these purposes. This is the transition of Rothko into abstract painting.

His work is difficult, sometimes impossible to interpret using words. Words are direct. They do not convey the whole range of meanings revealed in his paintings. Nevertheless, authors will try to do this. Authors will analyse the content of some paintings, guided by the symbols of space, where its lower part symbolizes the unconscious person, and the upper - the conscious part of the psyche. 
Let's consider the relationship of black and red in the paintings of the master. Red is the colour of the targeted activity. Activity as a form of manifestation of human energy arises in the depths of the unconscious (Black, Red and Black and a number of other paintings on this subject) (Rothko, 1968). This activity manifests itself as pure energy. This energy can be directed to various purposes. At the same time, goals can be both creative (Ochre and Red on Red) (Rothko, 1954), and destructive (Black and Orange on Red) (Rothko, 1962).

Studying the emotional manifestations of the human soul, he first of all was engaged in the understanding of his own soul. The author of Rothko's biography, J. Breslin, notes that the painting of the next picture was quick. However, before starting this work, the artist spent his days in meditation (Breslin, 1993). Talented artists feel the pulse of time. This is manifested in their works.

In 1962, the Caribbean or Cuban (Cuban missile crisis) crisis occurred. The world was on the brink of nuclear war. Humanity, like before the Second World War, was surrounded by an atmosphere of fear. Doctor of psychology, Professor V. King from the USA reported about those times as very scary: "We built bomb shelters and prepared for war," she said. V. King is a specialist in the field of psychosynthesis. In this direction, an important role belongs to the work with symbols (King, 2001).

Rothko had a deep feeling for these events. As a result, his view of his own painting changes. The space of the picture is no longer split into colour fragments and becomes monophonic. Increasingly, the black colour begins to dominate the metaphysical colour of the Cosmos. As noted by I.O. Ignatov, "the previously accumulated experience of portraying anxiety, fear or alienation prompted Rothko to attempt to convey the tragedy of human existence at a more generalized level" (Ignatov, 2013).

Through colour the artist tried to unravel the secrets of the human soul. It is not known how he succeeded. By the end of his life, he seemed to understand that the knowledge of the human soul is impossible without knowing the secrets of the universe, since the human soul is part of the metaphysical Cosmos.

You can feel the metaphysics of Rothko's paintings, left alone with the image. One of the students of these lines works in the master's program "Arts". Some time ago, the student was left alone with the work of his choice. In the hall where the paintings were exhibited, the lights turned off, and the respondent tried for 30 minutes to "feel/understand" the work.

The associations that were born during this time were fixed. The reactions were different. Cases were recorded when the respondent could not stand the time interval of 30 minutes and began to cry. On the other hand, students noted in the reports that they began to understand much better the artist's work. Here is a fragment of one of these reports. Its author is the prospective master of Arts Evita Kleina: "There are times when we feel confused or unaware of it. Emotions are expressed in words, liberates us. How to access one's hidden emotions? The answer is: through artwork. The search on the internet for many paintings by Mark Rothko is possible (those with only colour spaces and without images). We intuitively select the one that describes the feeling of the moment best of all. With the eyes, it is often much easier to 'find' the right words than with the mind. Indulge in the message that the colours tell you. And now, write down everything that comes to mind on a piece of paper. You will be amazed at how many relationships you can draw from your newly written and personal life. The written message contains all your concerns, suspicions, joy or anxiety. All I have to do is decipher it by asking myself how each written word fits into my life; where I have heard it before; why do I express my emotions precisely with this word or image. All the answers are within us! All the answers are in the artwork". (The report is stored in the authors' archive).

The process of students' work with Rothko's paintings is illustrated in Figure 3.

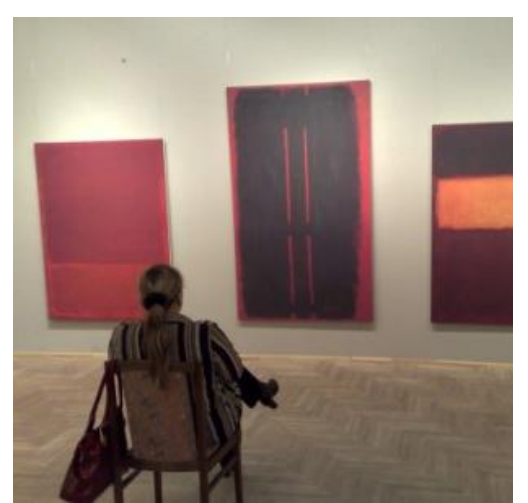

Figure 3. The work of students with the paintings by Rothko.

Rothko's works have aesthetic value. As N. Azarenko notes, whether he wanted to or not, he managed to find combinations of shades that are valuable on their own, in their minimalism and purity, regardless of the meaning that he put into them (Azarenko, 2017). 


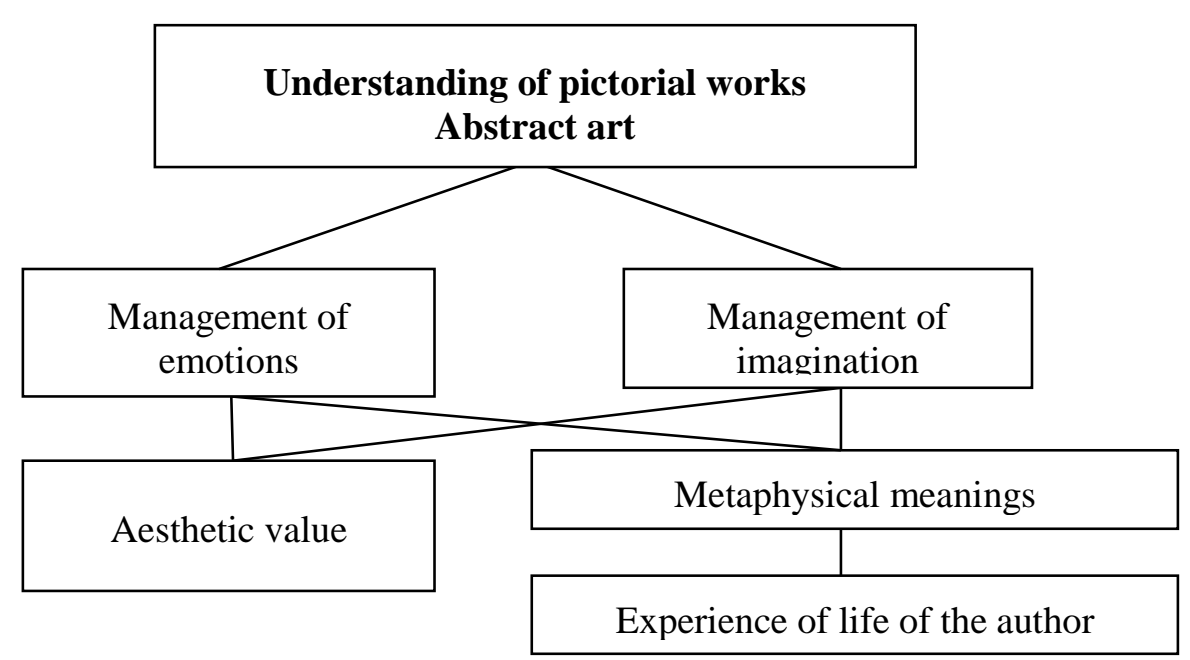

Figure 4. The algorithm for understanding abstract paintings.

Summarizing the above said, we will present the algorithm of analysis of abstract products. Figure 4 illustrates this point of view.

\section{Cinema discourse}

The principles of figuratively semantic analysis can also be applied to cinematic works. The main difficulty here is that films in which their authors use a symbolic language rarely appear on the screen.

We have already mentioned in the article about the Robert Altman's film "Vincent and Theo", where the author uses spatial symbolism, as well as the symbolism of objects and symbolism of colour. This group of films includes the work of director Peter Greenaway. In some of his films, he uses the symbolism of numbers (Altman, 1990). Without knowledge of symbolism, such films are difficult, and sometimes impossible to understand.

This film includes the work of Kenneth Branagh's director Frankenstein (Branagh, 1994). The plot is based on the novel of the same name by M. Shelley. The novel is about a young talented scientist Victor Frankenstein. He was very attached to his mother. But the mother suddenly dies. Shocked by this, Victor decides to devote his career to solving the riddles of life and death. Experimenting with the bodies of dead people, he creates a creature that he manages to revive. However, this creature is aggressive and begins to hunt people close to Frankenstein (Shelley, 2008).

Movie specialist screenwriter S. Lady and F. Darabont and actor and director K. Branagh used this plot, but they put different meanings into it. This is a psychoanalytic study of the human unconscious, the essence of which becomes clear when we manage to decipher the symbolism used in the film. (Branagh, 1994).

Art historians do not see this symbolism, so their analysis of the film is superficial. K. O'Shea compares the plots of the novel and the film and discusses about the appropriateness of certain deviations from the plot lines of the novel (O'Shea, 2019). The search for the meaning of the film lies in a completely different system.

As W.E. Smithe notes such diverse traditions as behaviourism, psychoanalysis, and modern computational psychology or information processing psychology support a certain view of symbolism. Psychoanalysis was borrowed from a completely different tradition in the study of symbols. This tradition emphasizes the mythological and metaphorical aspects of symbolism (Smithe, 1984). This tradition is continued by the authors of the film Frankenstein.

This film about the Oedipus complex, which, according to classical psychoanalysts, is the central formation of the personality unconscious at an early age. According to S. Freud (1989), the Oedipus complex manifests itself in an unconscious love for a parent of the opposite sex and the desire to get rid of an opponent - a parent of the same sex as the child. These childhood experiences can persist in an unconscious person and affect his life choices. The film begins with the appearance of Frankenstein family home. Its walls are painted red (with thin yellow stripes). The roof - without any other colour accents is blue. From the point of view of colour psychology, blue symbolizes the male principle (although it has other meanings: the symbolism is ambiguous). 
Red is the feminine principle. However, the characters at the beginning of the movie are dressed very differently. Victor's mother is in blue. Victor's shirt is blue. In contrast, the father at the ball is dressed in red clothes.

In this house there are two parties - blue (the mother, as evidenced by the colouring of that part of the exterior of the house, which protects from storms and rains) and red (the father subordinate to her). Victor is very attached to his mother. What favours the formation of the Oedipus complex?

But then something irreparable happens. During the childbirth, the mother dies. In desperation, Victor decides to devote his life to solving the problem of immortality. And he succeeds. The creature collected from the parts of the bodies of the people of the lower classes manages to revive. It begins to live its own life. In the film, the creature has no name. In A. Freud's psychoanalytic theory, It is a part of the human psyche that is completely unconscious. It has no moral limitations. But its manifestations depend on the social environment.

The creature goes on a journey. It rises to the mountains. Hera is a symbol of the Self according to C.G. Jung (Jung et al., 1964). The path to the Self begins with the knowledge of the personal unconscious. Settling in a peasant hut, he seeks to master cultural skills. In it there is a need to be accepted into the community of these people, to find friends in them. However, his first attempt to get closer to these people was met extremely aggressively that activated his destructive forces.

These episodes of the film directly illustrate the psychoanalytic propositions. If a child grows up in a favourable psychological atmosphere, the Oedipus complex disappears. Moreover, it can serve as a source of humane and creative human activity. Aggressive social environment strengthens the destructive forces that this complex contains. By recalling the paintings of Rothko, the energy that appears in the depths of the human psyche is neutral. However. it manifests itself in human actions and can acquire both a constructive and a destructive orientation.

The creature starts from the mountains and begins its destructive activity. He sequentially kills the younger brother of Victor, his father and his bride, who has just become his wife. Why is he doing this?

Because he is a part of the personality of Victor himself, her deep, unconscious structures. It fulfils Victor's secret and unconscious desires. The younger brother died because he became the involuntary killer of his mother, the only woman Victor loved. Father was his rival. The bride was not his choice and it was his mother's choice.

And here we come to the answer to the main question of our study. What did the authors want to say on their film (Branagh, 1994)? But, before answering this question, we consider the features of the appearance of the two characters in the picture.

This is it and the resurrected bride wife of Victor Frankenstein, Elizabeth. They say that the eyes are a mirror of the soul. Therefore, the resurrected man has no left eye. The resurrected Elizabeth is right.

The left eye symbolizes Anima, the feminine in the soul of a man. Anima balances the natural aggressiveness of a man. The absence of a woman's right eye means the absence of Animus in her soul.

The Animus, or Logos, balances the naturally based feminine emotional sensitivity. In the absence of Animus, a woman can burn in the fire her feelings. Which literally happens in the film with Elizabeth.

The ancient sages claimed that the like is created by the like. A human being is not perfect. It is impossible to know oneself completely. By artificially creating one's own kind, human beings are not given to know what part of their-self they give to these creatures. Only nature possesses perfection, or God. The film has a symbol of the cross. However, this is not a Christian cross.

\section{Conclusions}

Symbolism is ambiguous. Originating in the early historical period, it can change under the influence of the characteristics of cultural representations of an ethnos or a group of ethnos that are close in their views.

Moreover, the individual experience of a person can also change the idea of the essence of the content of a symbol. For example, white colour in Latvian and European culture as one of its meanings has the 
beginning of a new stage of life. For the residents of many countries of the Muslim East - this colour of mourning, that is, the colour of the end of life's journey. However, here it should be noted that for a Muslim the end of one life's journey does not mean the existential death. The existence continues at another existential level.

If a child was sick as a child, and the doctor often came to him/her in a white dress and gave unpleasant injections, then he/she may have a strong connection between white and the feeling of pain. The meaning of paintings is based on an archetypal (colour) or culturally related symbolism (subject). However, as it was said at the beginning of the article, one of the most important properties of perception is awareness.

This means that knowledge of certain historical conditions that contributed to the emergence of the picture, to the understanding of what is depicted in the picture, as well as an orientation in the experiences of the artist himself, which could be reflected in the plot of his work, can help to get closer to the understanding of those ideas that the author would like to bring to the mind of the viewer.

For the psychology of art, the main problems are the study of creative personality and peculiarities of spectators', readers' or listeners' perception of art. It helps to understand the meaning of works of art:

- knowledge of symbolism;

- knowledge of the peculiarities of the author's life path.

Van Gogh's painting is connected with peculiarities of his personality. According to Lusher's classification, Van Gogh is characterized by a yellow type of behaviour. A knowledge of history, symbolism of space, and object symbolism conduces to an understanding of Velasquez's painting. The colour set of Repin's paintings depends on emotional state of the author. Figuratively semantic analysis can be applied to all types of visual art.

\section{Bibliography}

1. Adamcik M. (2014). Simvoli vsevo mira [Symbols of the whole world]. Minsk: Harvest. (in Russian)

2. Alpers S. (1984). The Art of Describing: Dutch Art in the Seventeenth Century. Chicago: University of Chicago Press.

3. Altman R. (Director). (1990). Vincent \& Theo. [Motion picture]. France, Great Britain, Netherlands: Arena Films, Belbo Films, Central Films.

4. Azarenko N. (2017). Pocemu kartini Marka Rotko - eto iskusstvo? [Why are Mark Rothko's paintings are considered as art?]. Retrieved from:

https://artchive.ru/publications/2624 Why_are_Mark_Rothkos_paintings_considered_art (in Russian).

5. Battistini M. (2005). Symbols and Allegories in Art. Los Angeles: J. Paul Getty Museum

6. Branagh K. (Director). (1994). Frankenstein. [Motion picture]. USA, Japan: Tristuar Pictures.

7. Breslin J.E.B. (1993). Mark Rothko: A Biography. Chicago: The University of Chicago Press.

8. Chauhan B.S. (2015). Impact of psychology in art. International Journal of Engineering Sciences \& Management Research, 2(2), 43-45. Retrieved from: http://www.ijesmr.com/doc/Archive2015/February-2015/5.pdf

9. Freud S. (1989). Introductory Lectures on Psycho-Analysis. New York: Liveright Publishing Corporation.

10. Gage J. (2000). Colour and Meaning: Art, Science and Symbolism. Berkeley: Los Angeles University of California Press.

11. Giorgione. (1503). Castelfranco Madonna. [Painting, oil on canvas]. Cathedral of Castelfranco Veneto Italy. Retrieved from: https://www.artble.com/artists/giorgione/paintings/castelfranco_madonna

12. Hall J.A. (2014). Dictionary of Subjects and Symbols in Art ( $2^{\text {nd }}$ ed.). London: Routledge.

13. Huyghe R. (1967). Van Gogh. New York: Crown Publishers.

14. Ignatov I.O. (2013). Probljema prostranstvo i cveta v pozdnjem tvorčesteve Marka Rotko [The problem of space and color in the late work of Mark Rothko]. Avtoreferat disertacii na soiskanije ucenoi stepenji kandidata isskusstvovedjenija. Moskva: Moskovskaja gosudarstvennaja hudozjestvennopromishljennaja akademija imenji S.G. Stroganova. (in Russian)

15. Jung C.G., Von Franc M.L., Henderson J.L., Jacoby J., Jaffe A. (1964). Man and his Symbols. New York. Doubleday.

16. Jung C.G. (2003). Psychology of the Unconscious. New York: Dover Publications. 
17. Kalēja-Gasparoviča D. (2012). The students' creative experience enrichment in visual art studios. In V. Dislere (Ed.), The Proceedings of the International Scientific Conference Rural Environment. Education. Personality (REEP), 5. Jelgava: LLU, 223-230. Retrieved from:

https://llufb.llu.lv/conference/REEP/2012/REEP-2012-proceedings-E-ISSN-2255-808X.pdf\#page=224

18. Kamali N., Javdan M. (2012). The Relationship between art and psychology. Journal of Life Science and Biomedicine, 2(4), 129-133. Retrieved from: http://jlsb.science-line.com/attachments/article/16/JLSB2012- B26, 129-133.pdf

19. King V. (2001). Five forces of psychology. In V. Makarevičs (Ed.). Tolerance un citas psihologiskās un pedagogiskās problēmas. Daugavpils: Saule, 100-103.

20. Kok L. (2018). Expert Advice on How to Look at Paintings. Catawiki. Retrieved from: https://www.catawiki.com/stories/875-expert-advice-on-how-to-look-at-paintings

21. Lüscher M. (1985). Der Lüscher-Test. Persönlichkeitsbeurteilung durch Farbwahl [The Luscher test. Personality assessment through colour choice]. Reinbek: Rowohlt. (in German)

22. Lüscher M. (2005). Der 4-Farben-Mensch. Wege zum inneren Gleichgewicht (7 $7^{\text {th }}$ ed.). Ullstein Taschenbuch. (in German)

23. Makarevičs V. (2009). The Analysis of Symbolism of Colour in the Film "Vincent and Teo". In the Scientific Articles International Conference Person. Colour. Nature. Music., 6. Daugavpils: Universitātes akadēmiskais apgāds "Saule", 72-79

24. Makarevičs V. (2017). Art psychology: a symbolic painting analysis. In V. Lubkina, A. Zvaigzne (Eds.), The proceedings of the International Scientific Conference Society. Integration. Education. 4. Rezekne: Rezekne Academy of Technologies, 76-86. doi: 10.17770/sie2017vol4.2427

25. O'Shea K. (2019). Mary Shelley's Frankenstein (1994): A Retrospective. Warped Perspective. Retrieved from: http://warped-perspective.com/index.php/2019/08/11/mary-shelleys-frankenstein-1994-aretrospective/

26. Repin I. (1870-1873). Barge haulers on the Volga. [Painting]. Retrieved from: https://en.wikipedia.org/wiki/Barge_Haulers_on_the_Volga

27. Repin I. (1903). What space! [Painting]. Gallerix. Retrieved from: https://gallerix.org/album/Repin/pic/glrx-833474731

28. Repin I. (1906). Demonstration on October, 17, 1905. [Painting, oil on canvas]. Retrieved from: https://www.wikiart.org/en/ilya-repin/demonstration-on-october-17-1905-sketch-1906

29. Rideal L. (2015). How to Read Art: A Crash Course in Understanding and Interpreting Painting. Rizzoli International Publications.

30. Rothko M. (1937). Street Scene. [Painting, oil on canvas]. Washington, DC: National Gallery of Art. Retrieved from: https://www.nga.gov/collection/art-object-page.67378.html

31. Rothko M. (1938). Entrance to the Subway. [Painting]. Visual Art Encyclopaedia. Retrieved from: https://www.wikiart.org/en/mark-rothko/entance-tosubway\#: :text=Entrance\%20to\%20the\%20Subway\%20(1938,his\%20studies\%20at\%20Yale\%20University

32. Rothko M. (1954). Ochre and Red on Red. [Painting]. Retrieved from: https://www.markrothko.org/ochre-and-red-on-red.jsp

33. Rothko M. (1962). Black and Orange on Red. [Painting]. South Korea: Leeum, Samsung Museum of Art. Retrieved from: https://www.artsy.net/artwork/mark-rothko-untitled-black-and-orange-on-red

34. Rothko M. (1968). Black, Red and Black. [Painting]. Madrid, Spain: Thyssen-Bornemisza Museum. Retrieved from: https://www.wikiart.org/en/mark-rothko/black-red-and-black-1968

35. Shelley M. (2008). Frankenstein. London: One world Ckassics Limited.

36. Smithe W.E. (1984). Psychology and the Traditions of Symbolization. Advances in Psychology, 19, 45-63. doi: 10.1016/S0166-4115(08)62344-4

37. Solso L. (2003). The Psychology of Art and Evolution of the Conscious Brain. Cambridge: MIT Press.

38. Sturgis A. Clayson H. (Eds.). (2000). Understanding Paintings: Themes in Art Explored and Explained. New York: Watson-Guptill.

39. Van Gogh V. (1890). Wheatfield and Crows. [Painting, oil on canvas]. Amsterdam: Van Gogh Museum. Retrieved from: https://www.vangoghmuseum.nl/en/collection/s0149V1962

40. Velázquez D. (1618). Christ in the House of Martha and Mary. [Painting, oil on canvas]. London: National Gallery. Retrieved from https://en.wikipedia.org/wiki/Christ_in_the_House_of_Martha_and_Mary_(Vel\%C3\%A1zquez)

41. Vygotsky L.S. (1971). The Psychology of Art. Cambridge: MIT Press. 